*For correspondence: Alex.Sigal@ahri.org (AS)

\section{Interference with HIV infection of the first cell is essential for viral clearance in a pre-exposure prophylaxis model}

\author{
Ana Moyano De Las Muelas ${ }^{1,2}$, Gila Lustig ${ }^{1}$, Hylton E. Rodel ${ }^{1,2}$, Tibor Antal $^{3}$, Alex \\ Sigal ${ }^{1,2,5^{*}}$
}

${ }^{1}$ Africa Health Research Institute, Durban, South Africa; ${ }^{2}$ School of Laboratory Medicine and Medical Sciences, University of KwaZulu-Natal, Durban, South Africa; ${ }^{3}$ School of Mathematics, University of Edinburgh, Edinburgh, UK; ${ }^{5}$ Max Planck Institute for Infection Biology, Berlin, Germany

12 Abstract Pre-exposure prophylaxis (PrEP) uses relatively weak HIV inhibition to reduce transmission between individuals. Why this approach is successful is unclear. Here we derive and experimentally validate a mathematical model for predicting infection clearance with PrEP based on the measured effect of a drug on the HIV replication ratio and number of initial infected cells. We tested the model by inhibiting low dose HIV infection with tenofovir, which reduces infection frequency per cell, and atazanavir, which reduces the cellular burst size of viable virions. Both drugs were at concentrations which allowed similar HIV replication. Reducing infection frequency dramatically increased infection clearance, while reducing burst size did not. This indicates that initial infection is vulnerable to inhibition before it infects the first cell, but not thereafter. Our model explains why PrEP is potent at drug concentrations which are ineffective against established infection, and provides a framework to test drug effectiveness for PrEP.

\section{Introduction}

Antiretroviral therapy (ART) currently used to treat ongoing HIV infection combines several potent antiretroviral drugs (ARVs). Yet, no current ART regimen has been successful in extinguishing infection once it is established in the human host (Churchill et al. (2016); Sigal and Baltimore (2012)). In contrast to the robustness of HIV infection once established, initial HIV transmission between an infected and uninfected individual is more fragile. The probability for an exposed individual to become infected does not exceed 0.02 per sexual act under any set of conditions and is usually much lower (Gray et al. (2001); Jin et al. (2010)). It generally involves one founder viral clone (Keele et al. (2008)). This indicates that an infection bottleneck exists, where most infection attempts by transmitted virions are unsuccessful.

The probability of initial transmission has been shown to be effectively reduced with a single ARV if the ARV is present before exposure takes place, an approach termed PrEP. The ARVs used for PrEP are a subset found in the full treatment regimen. A central agent is tenofovir (TFV), which interferes with viral reverse transcription and is usually delivered as the prodrug tenofovir disoproxil fumarate (TDF) or tenofovir alafenamide fumarate (TAF). TFV is either used by itself or co-administered with emtricitabine (FTC), another HIV reverse transcriptase inhibitor. This approach 
Established infection

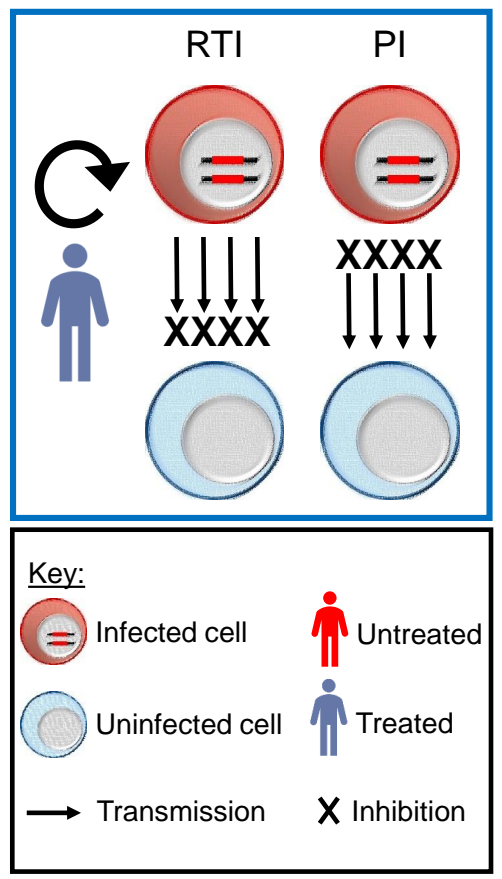

PrEP

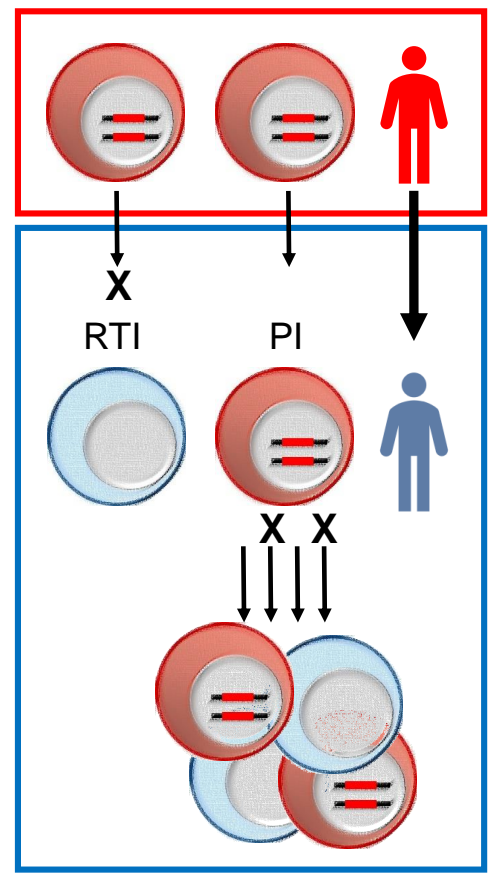

Figure 1. Inhibition of established versus transmitted infection. Left panel shows established infection in an individual, where both the infected donor cell and uninfected target cell are exposed to antiretroviral drugs. In this case, a complete block of transmission is illustrated, with infection persisting in a reservoir of long lived infected cells. Right panel shows infection in PrEP, where the virus is produced in an infected individual where suppression of infection by drugs is absent or ineffective. The virus is then transmitted to an uninfected, PrEP treated individual. Two drug mechanisms of inhibition are shown: Reverse transcriptase inhibitors (RTI) and other ARVs such as integrase inhibitors reduce infection frequency by blocking HIV from becoming a provirus in the host DNA capable of making new infectious virions. Protease inhibitors (PI) reduce the burst size of infectious virions per infected cell by interfering with HIV maturation, a process which requires cleavage of HIV proteins by the HIV protease.

was shown to be effective in a non-human primate model of low dose infection, even when dosing was intermittent (García-Lerma et al. (2008)). In contrast to PrEP, TFV and FTC are only used in combination with a highly potent ARV such as dolutegravir or efavirenz to suppress established infection (https://aidsinfo.nih.gov/guidelines/html/1/adult-and-adolescent-arv/11/what-to-start).

The majority of clinical studies have shown PrEP effectiveness in a variety of populations, transmission modes, and drug delivery modalities (Baeten et al. (2012); Choopanya et al. (2013); McCormack et al. (2016); Molina et al. (2015); Thigpen et al. (2012); Grant et al. (2010); Karim et al. (2010); Baeten et al. (2016); Nel et al. (2016)). These include studies utilizing oral TDF alone (Baeten et al. (2012); Choopanya et al. (2013)), oral TDF/FTC (Baeten et al. (2012); McCormack et al. (2016); Molina et al. (2015); Thigpen et al. (2012); Grant et al. (2010)), TFV gel (Karim et al. (2010)), and vaginal rings containing the reverse transcriptase inhibitor dapivirine (Baeten et al. (2016); Nel et al. (2016)). Currently, PrEP is indicated when there is a high likelihood of HIV infection due to sexual contact with an HIV infected individual or injectable drug use (WHO (2015); Anderson et al. (2012)) and may be used in conjunction with other prevention measures to reduce HIV incidence (Punyacharoensin et al. (2016); Pretorius et al. (2010)). The reason to use a weakened ARV regimen is partly to decrease side effects and thus make it more acceptable to healthy individuals (Choopanya et al. (2013); Koechlin et al. (2017)).

Why weak inhibition relative to the replicative capacity of HIV is effective in PrEP has not been investigated theoretically or experimentally, and such understanding may guide the development of new PrEP approaches. Currently approved ARVs include drugs which target various stages of 
We first set out to model the effect of reducing infection frequency and burst size on the probability to clear infection $\left(P_{c}\right)$. We model the infection chain of HIV transmissions between cells by using a branching process (Athreya et al. (2004)). We consider the initial stages of HIV infection, where host cells are not limiting in the number of cells that can be infected (Ribeiro et al. (2010); Nowak and May (2000)). An infected cell produces a burst of $\kappa$ virions. $\kappa$ is on the order of $10^{3}$ to $10^{4}$ (Eckstein et al. (2001); Chen et al. (2007)). The probability of one virion infecting the next cell is $r$, the infection frequency. We note the maximum number of cells which can be infected per burst is $\kappa$. A key quantity is the product $R_{0}=r \kappa$ (Nowak and May (2000)). $R_{0}$ is approximately 10 in vivo (Ribeiro et $a l$. (2010)). Eventual infection clearance is certain for $R_{0} \leq 1$. For $R_{0}>1$, infection may still be cleared if, at any point in the infection chain, the number of infected cells is zero. Hence, we define the probability that infection is cleared as:

$$
P_{c}:=\operatorname{Prob}\left\{N_{i}=0 \text { for any } i\right\},
$$

94 where $N_{i}$ is the number of infected cells in the $i$-th transmission step.

the viral life cycle (http://aidsinfo.nih.gov/). Among the most commonly used are inhibitors of the HIV proteins reverse transcriptase, integrase, and protease. Reverse transcriptase and integrase inhibitors prevent the initial infection of the cell but do not interfere with viral production from an already infected cell. Protease inhibitors do not interfere with cellular infection but reduce the number of viable virions an infected cell produces by interfering with virion maturation, which requires the HIV protease. Hence, the two mechanisms of inhibition involve either decreasing HIV infection frequency or viral burst size (Delbrück (1945)) per infected cell. However, it has been

orted that protease inhibitors decrease infection frequency to some extent (Rabi et al. (2013)). successful infections will be decreased if virions are prevented from infecting a cell by blocking their ability to become a provirus capable of generating new virions. It will also be decreased by reducing the output of new viable virions from an infected cell. In either case, fewer virions are available for the next cycle of infection (Figure 1, left panel). Whether or not infection expands is determined by the replication ratio $R_{0}$, which measures the mean number of new cells infected by a single infected cell. Given that $R_{0}=r \kappa$, where $r$ is the probability of infection and $\kappa$ the viral burst size per cell (Ribeiro et al. (2010); Nowak and May (2000)), decreasing $R_{0}$ should be possible by either decreasing $r$ or $\kappa$. The exception to the symmetrical effects of the two drug mechanisms on HIV replication is when the virus originates at low numbers in a different individual. In this case, PrEP is applied to the yet uninfected, exposed individual. In HIV infection, if transmission is by cell-free virus (Jackson et al. (2018); Boullé et al. (2016); Sigal et al. (2011); Kim et al. (2018)), using a drug which reduces burst size may not affect the incoming virus in the first infection cycle, since that virus is already mature (Arts and Hazuda (2012)). In contrast, a regimen which decreases infection frequency may be effective in preventing the incoming virus from infecting the first cell in the new host (Figure 1, right panel). After initial infection, both inhibitors should act symmetrically. Whether this difference between inhibitor mechanisms is important in determining the clearance probability the probability that infection will be terminated as a consequence of the inhibitor - is unknown. the replication ratio $R_{0}$, both of which we measured experimentally. We used two types of inhibition: reduction of infection frequency mediated by TFV, and reduction of the burst size of viable virions mediated by atazanavir (ATV), a drug belonging to the class of HIV protease inhibitors. We observed that while both drugs reduced $R_{0}$ to a similar extent at the concentrations used, only TFV, which prevented successful infection of the first set of cells, was effective at clearing infection.

\section{Results}


We denote by $q$ the probability that infection starting from a single infected cell is cleared. In the biologically relevant case where $\kappa$ is large and $r$ is small, with $R_{0}$ finite, we can calculate $q$ as (see derivation in Materials and Methods):

$$
q=-R_{0}^{-1} W\left(-R_{0} e^{-R_{0}}\right) .
$$

Here, $W$ is the Lambert $W$-function (Gradshteyn and Ryzhik (2014)), the inverse of the function $g(x)=x e^{x}$.

As defined, $q$ is the probability that the infection originating in a single infected cell will be cleared. We note that in the case where host cells are not limiting, as occurs in the initial stages of infection, infection chains originating from individual infected cells are independent of each other. Hence, given $n$ initial infected cells,

$$
P_{c}=q^{n} .
$$

We consider the initial number of infected cells as a random variable from a distribution $\phi_{n^{\prime}}$ where $P_{c}=\sum_{n \geq 0} \phi_{n} q^{n}$. A biologically relevant choice in viral infection is the Poisson distribution $\phi_{n}=\lambda^{n} e^{-\lambda} / n !$, where $\lambda$ is the mean number of initial infected cells. Using $e^{x}=\sum_{n \geq 0} x^{n} / n !, \sum_{n \geq 0} \phi_{n} q^{n}$ then becomes:

$$
P_{c}=\sum_{n \geq 0} \frac{\left(q^{n} \lambda^{n} e^{-\lambda}\right)}{n !}=e^{\lambda(q-1)} .
$$

We now consider the effect of the antiretroviral drug mechanism on $\lambda$ and $q$. We note that ARVs reduce either infection frequency $r$ or burst size $\kappa$. For drugs which reduce infection frequency, $r \rightarrow d_{1} r$, and for drugs which reduce viral burst size, $\kappa \rightarrow d_{2} \kappa$, where $0 \leq d_{1}, d_{2} \leq 1$. Given $R_{0}=r \kappa$ and therefore $R_{0} \rightarrow R_{0} d_{1} d_{2}$, the effects of the drug mechanisms are symmetrical on $q$ :

$$
q_{d r u g}=-\left(R_{0} d_{1} d_{2}\right)^{-1} W\left(-R_{0} d_{1} d_{2} e^{-R_{0} d_{1} d_{2}}\right) .
$$

Hence, if the drugs decrease $R_{0}$ to a similar extent, their effect on $q$ will also be similar. However, given an initial transmission with cell-free virus, only the drug mechanism that decreases infection frequency will reduce the mean initial number of infected cells $\lambda$. The mechanism which reduces burst size will only affect the success of the next transmission cycle. Therefore, the probability to clear infection with ARVs becomes:

$$
P_{c}^{d r u g}=e^{\lambda d_{1}\left(q_{d r u g}-1\right)} .
$$

Here $q_{\text {drug }}$ is determined by Eq. (4). Given that $\lambda$ is expected to be small, on the order of one infected cell, the probability of clearance is expected to be very sensitive to the drug mechanism which reduces infection frequency $\left(d_{1}\right)$, provided the effect of the drug is present when initial infection takes place. The drug mechanism which reduces burst size $\left(d_{2}\right)$ misses this initial intervention point.

To visualize the effects of decreasing $R_{0}$ versus $\lambda$, we plotted Eq. (3) for a range of parameter values (Figure 2A). It can be observed that for $R_{0} \leq 1$, infection terminates. At $R_{0} \approx 1.5$, infection is not strongly sensitive to the exact $R_{0}$ value. However at all $R_{0}>1$ values, the probability of infection clearance is very sensitive to $\lambda$, provided $\lambda$ is small. This sensitivity is greatly reduced when $\lambda \gtrsim 2$.

To examine the effects of drug mechanism, we plotted infection clearance according to Eq. (5) at two conditions of $R_{0}$ and $\lambda$ relative to $d_{1}$ and $d_{2}$ (Figure 2B). In the first condition, $R_{0}$ was sufficiently small to be decreased below 1 by the drugs in the inhibition range used, while $\lambda$ was large. In the 
A

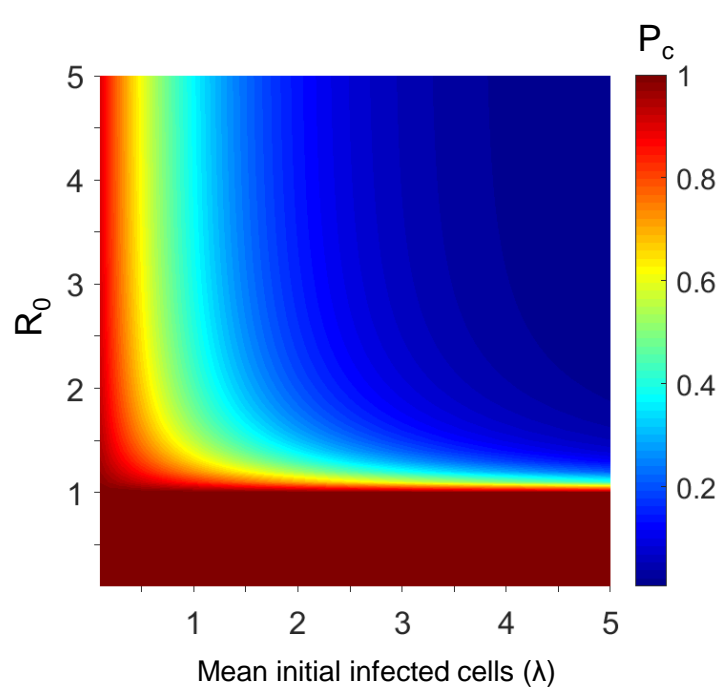

B

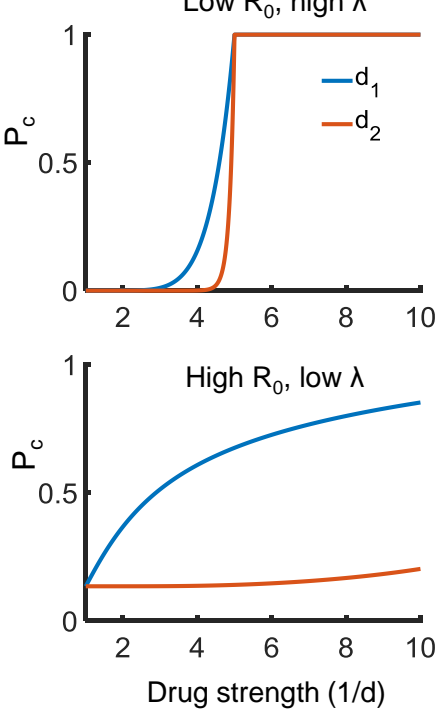

Figure 2. Effects of the initial infected cell number $\lambda$ and replication ratio $R_{0}$ on the probability of infection clearance $P_{c}$. (A) $P_{c}$ according to Eq. (3) at different parameter values for $\lambda$ and $R_{0}$. (B) $P_{c}$ according to Eq. (5) when a drug attenuating infection frequency $\left(d_{1}\right)$ or burst size $\left(d_{2}\right)$ acts on $\lambda$ and $R_{0}$. Top panel shows the case where $R_{0}=5, \lambda=20$, while bottom panel shows the case where $R_{0} .=20, \lambda=2$. X-axis is drug strength as $1 / d, \mathrm{y}$-axis is $P_{c}$

second condition, $R_{0}$ was large while $\lambda$ small. In the first condition, both drug mechanisms had a similar effect on infection clearance, and $P_{c}=1$ when the effect of either drug reduced $R_{0}$ below 1. In the second condition, only $d_{1}$, which decreased infection frequency, substantially increased $P_{c} . d_{2}$, which acted on burst size, had no appreciable effect. We note that based on observations of $R_{0} \approx 10$ in vivo (Ribeiro et al. (2010)) and a probability of clearance of at least 0.98 per exposure from an HIV positive partner in the absence of PrEP (Gray et al. (2001); Jin et al. (2010)) which is suggestive of a small value for $\lambda$, the second condition likely reflects the physiological situation.

\section{Experimental determination of the probability of infection clearance}

We examined experimentally whether Eq. (5) predicts $P_{c}$ for different drug mechanisms at a low number of initial infected cells, the likely in vivo condition for initial infection. We used the reverse transcriptase inhibitor TFV and the protease inhibitor ATV to inhibit infection initiating as cell-free HIV. We measured the effect of each drug on the initial number of infected cells $\lambda$ from cell-free infection and on $R_{0}$ after the first infection cycle. For virus, we used HIV NL(AD8), an HIV strain with a CCR5 tropic envelope protein. CCR5 tropism has been shown to be the predominant transmitted form between individuals (Keele et al. (2008)). As target cells for infection, we used a clone of the RevCEM infection indicator cell line (Wu et al. (2007)) which we first subcloned to increase detection efficiency (Boullé et al. (2016)) then modified to express the CCR5 receptor (RevCEM-B8, Materials and Methods). Detection of infected cells was done by detecting the number of GFP positive cells using flow cytometry.

We titrated TFV and ATV to obtain a similar effect on ongoing viral replication, which occurred at $60 \mu \mathrm{M}$ and $16 n \mathrm{M}$ of TFV and ATV respectively. We then infected cells in the presence of these drug concentrations and measured infection over time to precisely measure $R_{0}$ for each drug condition. We initiated infection with the same dose of cell-free HIV for each infection condition. After initiation of infection, ongoing infection was maintained by transmission through coculture of infected and uninfected cells. To maintain nutrients for cell growth and prevent the depletion of the uninfected target cell population, we passaged cells every two days by diluting infection with fresh medium 
A

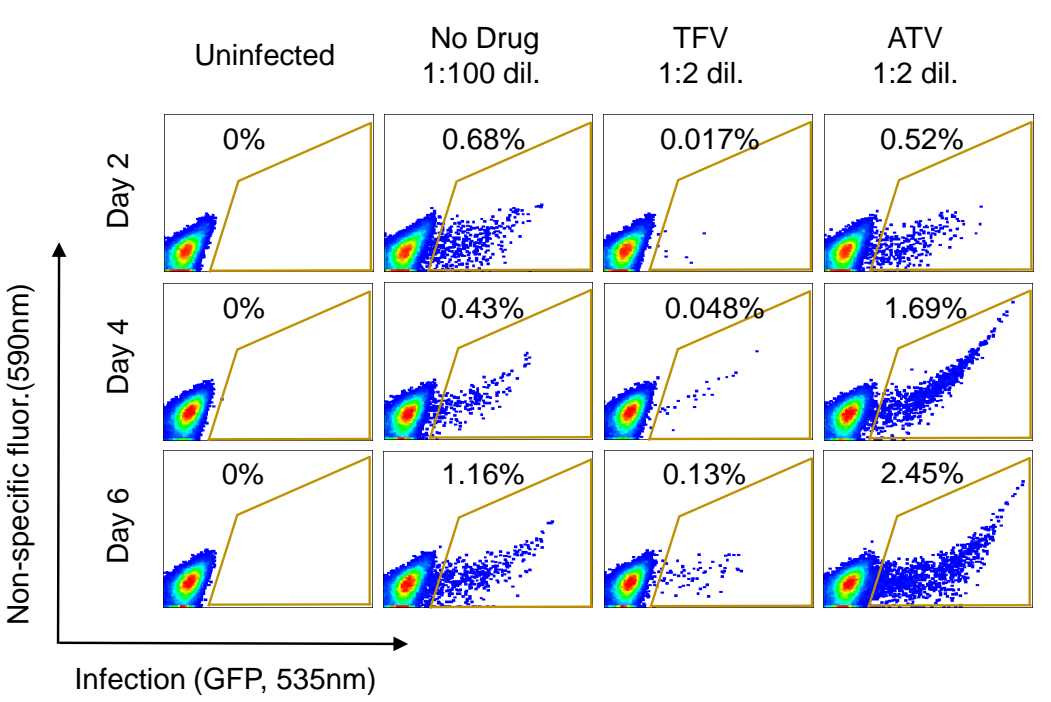

B

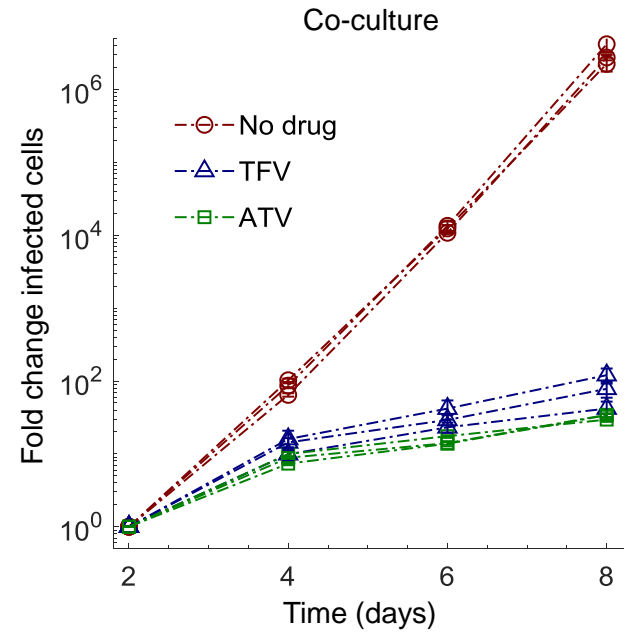

C

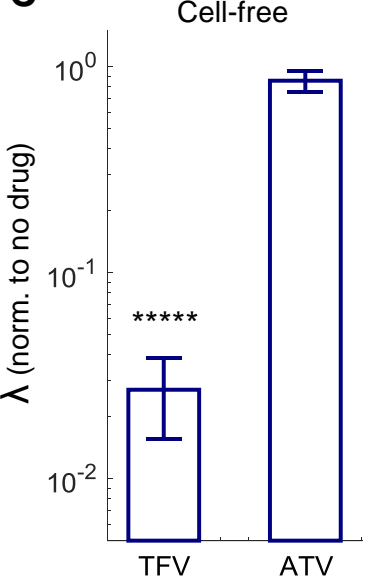

Figure 3. Experimental measurement of drug effect on $R_{0}$ and the initial number of infected cells $\lambda$. (A) Flow cytometry plots of the fraction of infected cells at different days post infection in the absence of drug or presence of $60 \mu \mathrm{M}$ TFV or $16 n \mathrm{M}$ ATV. Day 2 is the first time-point after the initial cell-free infection, corresponding to approximately one viral cycle. X-axis is GFP fluorescence, $y$-axis is autofluorescence, with the fraction of infected cells corresponding to the cells within the area outlined in yellow. Infected cell cultures in the presence of either drug were diluted 1:2 every 2 days. Infected cultures in the absence of drug were diluted 1:100 into uninfected cells every 2 days. (B) Measurement of $R_{0}$ in the absence and presence of drug. The number of infected cells at each time-point is normalized by the number of infected cells at day 2 and corrected for the dilution factor used in each infection cycle. 3 independent experiment were performed, with each point denoting the mean \pm std of 3 experimental replicates per experiment. Infection in the absence of drug is shown as red circles, TFV as blue triangles, and ATV as green squares. (C) Effect of drug on $\lambda$. For each drug condition $\lambda$ was measured 2 days after cell-free HIV infection and normalized by $\lambda$ for no drug. Mean \pm std of 3 independent experiments, where normalization was with $\lambda$ in the absence of drug as measured in the same experiment. Raw numbers of infected cells averaged over all experiments were $1.3 \times 10^{4} \pm 1.5 \times 10^{3}$ for no drug infection, $3.4 \times 10^{2} \pm 1.3 \times 10^{2}$ for TFV and $1.1 \times 10^{4} \pm 7.4 \times 10^{3}$ for ATV (mean \pm std). 
at a 1:2 ratio for infection conditions with drug. Proliferation of uninfected cells was sufficient to maintain uninfected cell numbers, and infection was below 5 percent for both drug conditions at all time-points, ensuring target cells were not limiting (Figure 3A). For the no drug condition, the infection expanded much more rapidly. Therefore, the infected cell culture was passaged by diluting the infected cells 1:100 every 2 days into uninfected cells. Infection was monitored over 8 days. Despite the use of the same HIV cell-free input dose, there were pronounced differences at day 2 between TFV and ATV (Figure 3A). This time-point reflects the results of the initial cell-free infection given an approximately 2 day viral cycle (Perelson et al. (1996)). Cell-free infection was strongly inhibited by TFV relative to no drug. In contrast, the effect of ATV on cell-free infection was much weaker. After the day 2 time-point, infection expanded with similar dynamics for both drug conditions, and much more rapidly when no drug was present.

We plotted the total number of infected cells, corrected for cells removed during passaging, versus time (Figure 3B). We then calculated the effect of drug on $R_{0}$ over a two day cycle (Table 1). $R_{0}$ values were calculated as $4.2 \pm 0.73$ for TFV and $3.2 \pm 0.088$ for ATV (mean $\pm \mathrm{std}$ ). $R_{0}$ for infection in the absence was $143 \pm 15$ in the cell line. We then measured the effect of the drugs on $\lambda$ after the first cycle of infection (day 0 to day 2), and compared the results to infection in the absence of drug. $\lambda$ in the presence of drug divided by $\lambda$ for the no drug condition $\left(\lambda_{\text {norm }}\right)$ was $0.027 \pm 0.014$ for TFV and $0.88 \pm 0.16$ for ATV, (Figure 3C, Table 1). The decrease in $\lambda$ for TFV versus ATV was significant $\left(p=6 \times 10^{-14}, t\right.$-test $)$.

Table 1. Measured Parameter Values.

\begin{tabular}{ccc}
\hline Treatment & $\lambda_{\text {norm }}$ & $R_{0}$ \\
\hline No drug & 1 & $143 \pm 15$ \\
$60 \mu M$ TFV & $0.027 \pm 0.014$ & $4.2 \pm 0.73$ \\
$16 n M$ ATV & $0.88 \pm 0.16$ & $3.2 \pm 0.088$ \\
\hline
\end{tabular}

We then set out to investigate whether TFV and ATV could increase the probability of clearance of low inoculum infection, corresponding to in vivo exposure. We used $6.3 \times 10^{3}$ viral copies (Materials and Methods), predicted to result in approximately 3 initial infected cells based on a regression of the number of infected cells versus input viral load (Figure 4A). Infection was initiated with the same cell-free viral dose for all conditions, and infected cells were cultured for 8 days in the presence of drugs. Steady state cell viability was maintained by passaging the culture using a 1:2 dilution of cells into fresh medium with drug. After 8 days, drug was washed away and infection amplified by growth for 6 days in the absence of drug, with passaging every 2 days, to detect the presence of any infected cells after drug treatment. For the no drug infection condition, it was sufficient to culture infection for 6 days to obtain a robust signal in terms of infected cells. The background level of GFP signal was estimated from uninfected cells (Materials and Methods). After amplification in the absence of drug for the TFV and ATV conditions, infection was either clearly visible or absent (Figure 4B).

We did not experimentally observe clearance of infection in the absence of drug. In the presence of TFV, clearance rose dramatically, with approximately three quarters of infections extinguished. In contrast, only a minor increase of infection clearance was observed with ATV (Figure 4C). Clearance with TFV was significantly higher relative to no drug and ATV, while ATV was not significantly different from no drug ( $p<10^{-5}$ and $p=0.37$, respectively, using bootstrap). Calculation of $P_{c}^{d r u g}$ based on Eq. (5) using the measured values for $\lambda$ and $R_{0}$ for each drug condition showed a similar trend to the experimental values, with a higher clearance probability for each condition relative to the experimental results. Hence, Eq. (5) was able to predict the relative effectiveness of each drug to terminate infection in an in vitro model of PrEP. 
A

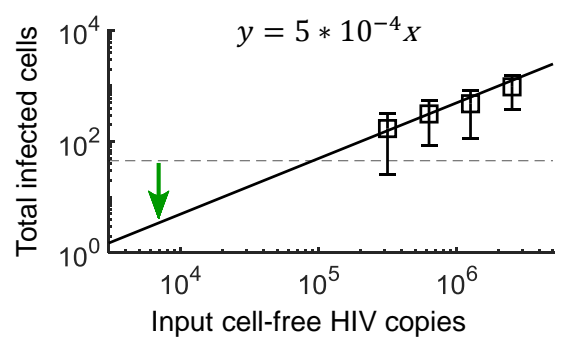

C

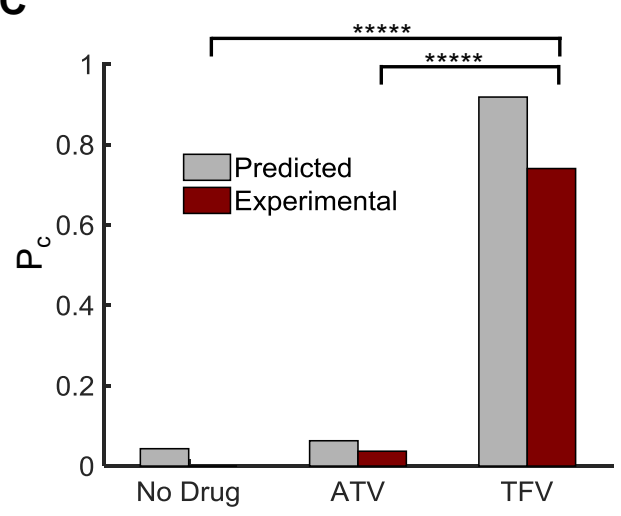

B

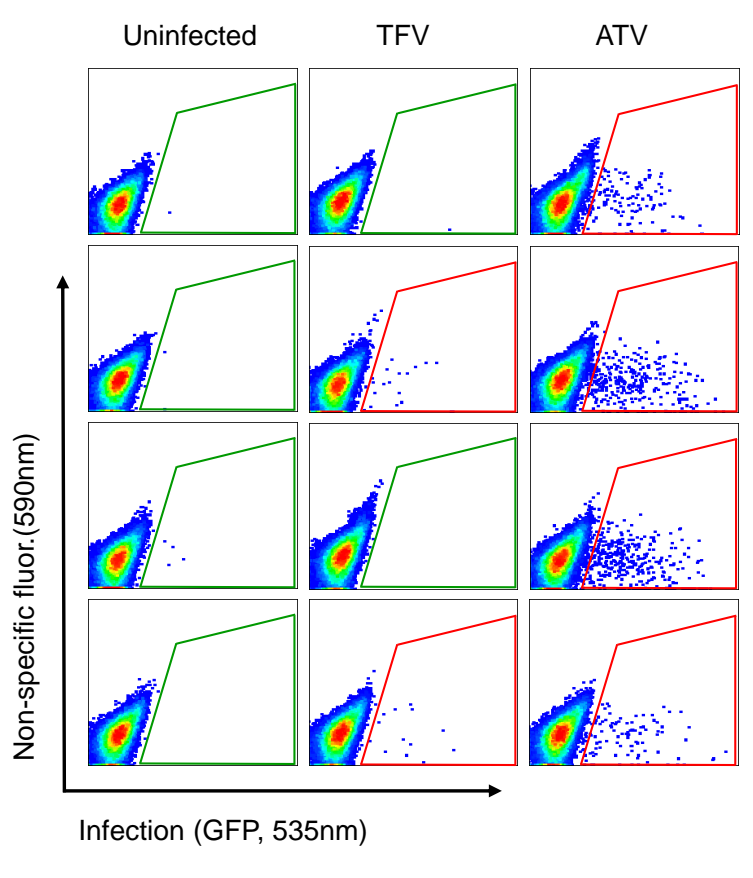

Figure 4. Probability of infection clearance depends on drug mechanism. (A) Determination of $\lambda$. The number of infected cells was measured using flow cytometry as a function of cell-free HIV RNA copies for four virus stock dilutions yielding a number of infected cells above the limit of detection after one infection cycle. Data was then fit using linear regression to determine the input viral dose for 3 infected cells. Mean \pm std of 5 independent experiments. Dotted line is limit of detection. Green arrow marks number of HIV RNA copies used in the experiments. (B) Representative flow cytometry plots after 8 days of infection with the input cell-free virus in the presence of of TFV or ATV and further 6 days amplification of the same infection in the absence of drug. Each plot represents one independently cultured replicate of the experiment. Uninfected samples are shown in the left column, and infection in the presence of TFV or ATV is shown in the middle and right column respectively. X-axis is GFP fluorescence, $y$-axis is autofluorescence. The fraction of infected cells corresponds to the cells within the area outlined in green or red, with green indicating background GFP signal level as determined from the uninfected samples, and red indicating above background signal. (C) $P_{c}^{d r u g}$ as predicted by Eq. (5) (gray bars) based on the measured drug effects on $R_{0}$ and $\lambda$, and as experimentally measured (red bars). Presence of infection was assayed in 26 (no drug) or 27 (TFV and ATV) cell-free virus infected cell cultures from 4 independent experiments. Observed $P_{c}^{T F V}$ was significantly higher than $P_{c}^{A T V}$ and $P_{c}^{\text {Nodrug }}\left(p<10^{-5}\right.$ by bootstrap). $P_{c}^{A T V}$ and $P_{c}^{\text {Nodrug }}$ were not significantly different ( $p=0.37$ by bootstrap). 


\section{Discussion}

In this study we modeled and experimentally measured the clearance probability of initial HIV infection in the face of different inhibitor mechanisms: attenuation of infection frequency (TFV) or viral burst size from the infected cell (ATV). We chose drug concentrations where replication was reduced but not fully suppressed to investigate the effect of suboptimal HIV inhibition. Given that PrEP regimens seem to be more likely to be subject to variable adherence relative to treatment of established infection (Van Damme et al. (2012); Marrazzo et al. (2015); Baeten et al. (2012); Choopanya et al. (2013); McCormack et al. (2016); Molina et al. (2015); Grant et al. (2014)), suboptimal inhibition is not only a function of the drug regimen but may be a feature of the approach. This may make achieving $R_{0} \lesssim 1$ more difficult than with therapy for established infection. Under this set of conditions and in agreement with model predictions, only TFV, the inhibitor which was able to act before the first cell was infected, was able to increase the probability of HIV clearance. The prediction was based on two parameters which were readily measurable: $\lambda$ is measured in one infection cycle with cell-free virus. $R_{0}$ is measured using multiple viral cycles, but consists of relatively simple passaging of infection to ensure that uninfected target cells are not limiting. Prediction does require the calculation of the the Lambert function. This can be done by a wide range of algebra capable programs (in this study we used Matlab).

We show that the current PrEP approach utilizing drugs which target infection frequency is in fact the correct choice. However, the quantitative model presented here has utility beyond giving a rationale for what is already done. For example, ARVs with longer half-lives such as the integrase inhibitor cabotegravir may become future treatment modalities both as ongoing therapy and for PrEP (Andrews and Heneine (2015)). However, longer half-lives also result in the drug levels reaching steady state slower, as the time to reach 50 percent of the steady state concentration is one half-life (Wagner (1975)). Therefore, in early exposures post-administration, level of inhibition for drugs with long half-lives may be lower for initial infection relative to drugs of the same class but with shorter half-lives. This may mean that the calculated $P_{c}$ may be different even among drugs which inhibit infection frequency and have similar effects on $R_{0}$. In contrast, how fast a drug is able to act post-administration may have little effect in suppressing established infection. These considerations may also shape the effectiveness of future therapeutic approaches such as vaccines which require antigen based immune recognition: if $R_{0}>1$ with the intervention, clearance would be unlikely if the immune mechanism is not rapid enough to prevent the first set of cells from being infected. Hence, under conditions where exposure may take place relatively rapidly post-PrEP dosing, the model presented here will be able to predict the relative PrEP utility of drugs of the same class at the level of cellular infection.

Factors in addition to drug effectiveness in inhibiting cellular infection may determine which drug or drug combination is used in PrEP. Among others, important considerations include drug side effects and interactions with other drugs (Grant et al. (2010); Anderson et al. (2010); Choopanya et al. (2013); Koechlin et al. (2017)), penetration to the initial site of infection (Anderson et al. (2010); Patterson et al. (2011); Spinner et al. (2016); Murnane et al. (2013); Baeten et al. (2013)), convenient dosing (Grant et al. (2010); Anderson et al. (2010); Baeten et al. (2013)), cost effectiveness (Nichols et al. (2016); Anderson and Cooper (2009); Paltiel et al. (2009); Desai et al. (2008); Pretorius et al. (2010); Hallett et al. (2011); Gomez et al. (2012)), and consequences that the use of the drug in PrEP will have on the transmission of resistant viral strains (Supervie et al. (2010, 2011); Dolling et al. (2012); Dimitrov et al. (2013); Abbas et al. (2013); Saenz and Bonhoeffer (2013); Van De Vijver et al. (2013); Okano and Blower (2013)). These additional factors need to be taken into account when designing a PrEP regimen.

The model output using the measured values for $\lambda$ and $R_{0}$ resulted in predicted probabilities of infection clearance which were higher than the experimentally observed clearance frequencies for all conditions. We speculate that the reason is an underestimation of the input number of infected cells $\lambda$. We measured $\lambda$ one viral cycle after cell-free infection. If GFP expression in an infected cell 
was below threshold of detection at that time, the cell would be missed in the assay yet still amplify infection. Despite this, the relative effectiveness of each drug mechanism was clearly predicted by the model. Factors in vivo which may result in deviation from model predictions include transmission by cell-to-cell spread (Sigal et al. (2011); Boullé et al. (2016); Jackson et al. (2018); Jolly et al. (2004); Duncan et al. (2014); Agosto et al. (2015, 2018); Law et al. (2016); Abela et al. (2012); Rudnicka et al. (2009); Sherer et al. (2007); Zhong et al. (2013); Del Portillo et al. (2011); Sowinski et al. (2008); Len et al. (2017); Baxter et al. (2014); Kim et al. (2018)). This should reduce the effectiveness of PrEP since the drugs would only act on $R_{0}$ and not on $\lambda$. A quantitative understanding such as presented here should detect deviations from the predictions made for cell-free infection, and thus allow a better understanding of any potential limits to PrEP.

HIV has been shown to rapidly seed a latent reservoir of infected cells (Chun et al. (1997a,b); Finzi et al. (1999); Siliciano et al. (2003); Eriksson et al. (2013)) which may also explain why it is necessary to block infection before the first cell is infected. However, at suboptimal inhibition, latent infection is not thought to play a role and infection is maintained by ongoing cycles of replication (Sigal and Baltimore (2012)). Evidence for this is the emergence of drug resistance with monotherapy (Deeks et al. (1997); Molla et al. (1996); Wei et al. (2002)). The current study provides a different rationale for why PrEP works best if the virus is inhibited before the first cellular infection, and enables a generalized evaluation of drugs to screen for the best candidates for this intervention.

\section{Materials and methods}

\section{Inhibitors, viruses and cells}

The following reagents were obtained through the AIDS Research and Reference Reagent Program, National Institute of Allergy and Infectious Diseases, National Institutes of Health: the antiretroviral drugs ATV and TFV; RevCEM cells from Y. Wu and J. Marsh; HIV-1 NL4-3 CCR5 tropic infectious molecular clone (pNL(AD8)) from E. Freed; pBABE.CCR5, from N. Landau. Cell-free virus was produced by transfection of HEK293 cells with pNL(AD8) using TransIT-LT1 (Mirus) transfection reagent. Supernatant containing released virus was harvested two days post-transfection and filtered through a 0.45 micron filter (GVS). The number of HIV RNA genomes in viral stocks was determined using the RealTime HIV-1 viral load test (Abbott Diagnostics). The RevCEM HIV infection GFP indicator cell line was modified as follows for experiments with the CCR5 tropic virus: The E7 clone was generated from RevCEM cells as described in Boullé et al. (2016). Briefly, the RevCEM cell line was sub-cloned by limiting dilution. Clones derived from single cells were expanded into duplicate 96-well plates, one optical and one standard tissue culture for continued growth. The optical plate was infected with NL4-3 and optical wells were scanned by microscopy to select clones with highest infection percentage by GFP expression. The clone E7 was selected based on $>70$ percent GFP positive cells upon infection, expanded from the uninfected replicate plate and frozen. To generate the CCR5 expressing B8 reporter clone, RevCEM-E7 cells were infected with the PBABE.CCR5 retroviral vector which stably expressed CCR5 under the LTR promoter. Cells were subcloned by limiting dilution. Clones derived from single cells were expanded into duplicate 96 -well plates, one optical and one standard tissue culture for continued growth. The optical plate was infected with $\mathrm{pNL}(\mathrm{AD} 8)$ and wells were scanned by microscopy to select clones which maintained similar GFP expression to the parental REVCEME7 clonal cell line. The clone RevCEM-B8 was selected based on $>70$ percent GFP positive cells upon infection, expanded from the uninfected replicate plate, and frozen. Cell culture medium was complete RPMI 1640 supplemented with L-Glutamine, sodium pyruvate, HEPES, non-essential amino acids (Lonza), and 10 percent heat-inactivated FBS (Hyclone).

\section{Infection and flow cytometry}

For determination of drug effect on $R_{0}$ and $\lambda$, cells were infected with $2.5 \times 10^{7}$ viral RNA copies in $2 \mathrm{ml}$ of cell culture containing $5 \times 10^{5}$ cells $/ \mathrm{ml}$. Every 2 days, the uninfected and drug treated cell 
cultures were passaged at a split ratio of 1:2, where half the cell culture was removed and fresh media with drug (for TFV and ATV) or without drug (for uninfected) was added. For the no drug infection condition, 1:100 of the culture $(20 \mu \mathrm{l})$ was added to $2 \mathrm{ml}$ of fresh, uninfected cells at $5 \times 10^{5}$ cells $/ \mathrm{ml}$. The removed fraction of cells was used to detect infection as follows: The number of infected cells was acquired every 2 days using 3 measurements of 30 second acquisitions per sample (approximately 50,000 cells/sample) with a FACSCaliber machine (BD Biosciences) using the $488 \mathrm{~nm}$ laser line. Flow rate on the machine was measured at each time-point, and acquisition time was multiplied by flow rate to obtain the number of infected cells per $\mathrm{ml}$. For experiments measuring $P_{c}^{d r u g}, 200 \mu \mathrm{l}$ of cells at a density of $5 \times 10^{5}$ cells $/ \mathrm{ml}$ were infected with $6.3 \times 10^{3}$ viral RNA copies. For cell cultures with either no infection or containing ATV or TFV, passaging conditions were the same as for the experiments used to determine drug effect on $R_{0}$ except that no culture was removed. Instead, new media with drug was added for the TFV and ATV conditions, and new media with no drug was added for the no infection condition. The infection volume therefore doubled every 2 days, and the cell culture was transferred to larger volume wells to preserve a constant surface to volume ratio. After 8 days (4 passages), cells were spun down, washed once in medium with no drug, and resuspended at $5 \times 10^{5}$ cells $/ \mathrm{ml}$ in fresh medium with no drug. Cells were then further passaged in the absence of drug for 6 days ( 3 passages) using a 1:2 dilution every 2 days to amplify any infection in the culture. For infection in the absence of drug, cells were passaged for 6 days (3 passages) using a 1:2 dilution every 2 days with fresh medium without removing any of the cell culture. The number of infected cells was acquired at the end of the experiment (14 days post-infection for the uninfected, TFV and ATV conditions and 6 days for the no drug infection condition) as 30 second acquisitions per sample with a FACSCaliber machine as above. Results were analyzed using Flowjo 10.0.8 software. The background frequency of positive cells was determined by acquiring uninfected samples ( $n=17$ from 4 independent experiments). A sample was scored as infected if the number of GFP positive cells was greater than that in the highest background samples (4 positive cells per 30 second acquisition).

\section{Statistical significance by bootstrap}

The vector of TFV results where infection was scored as either present (1) or absent (0) at each position in the vector, was resampled with replacement using $10^{5}$ iterations to determine the number of iterations which resulted in a vector of 26 1's (no drug) or 26 of 27 1's (ATV).

\section{Derivation of the mathematical model}

The probability that one cell with a burst of $\kappa$ virions will infect $m$ cells and not infect $\kappa-m$ cells is:

$$
P_{m}=\left(\begin{array}{c}
\kappa \\
m
\end{array}\right) r^{m}(1-r)^{\kappa-m},
$$

where $r$ id the infection probability per cell and $\left(\begin{array}{c}\kappa \\ m\end{array}\right)=\kappa ! / m !(\kappa-m) !$. We define the generating function for this probability distribution:

$$
p(s):=\sum_{m=0}^{\kappa} P_{m} s^{m} .
$$

Using the binomial formula $\sum_{i=0}^{n}\left(\begin{array}{c}n \\ i\end{array}\right) a^{n-i} b^{i}=(a+b)^{n}$, we obtain

$$
p(s)=\sum_{m=0}^{\kappa}\left(\begin{array}{c}
\kappa \\
m
\end{array}\right) r^{m}(1-r)^{\kappa-m} s^{m}=\sum_{m=0}^{\kappa}\left(\begin{array}{c}
\kappa \\
m
\end{array}\right) r s^{m}(1-r)^{\kappa-m}=(r s+1-r)^{\kappa} .
$$

For $R>1$, the extinction probability of infection is given by the smallest root of $p(s)=s$ (Grimmett and Stirzaker (2001)), that is:

$$
q=(r q+1-r)^{\kappa} .
$$


In the biologically relevant case where $\kappa$ is large and $r$ is small, with $R_{0}$ finite, we approximate the solution $(r s+1-r)^{\kappa}=e^{\kappa \ln (r s+1-r)}=e^{\kappa \ln (1+r(s-1))} \simeq e^{\kappa r(s-1)}$. Therefore,

$$
q=e^{-R_{0}(1-q)} .
$$

The solution for $q$ to this equation is presented as Eq. (1).

\section{Acknowledgments}

AS thanks Israel Michael Sigal for extensive discussions, and Deenan Pillay, Mark Siedner, and Brenda Tipper for comments on the manuscript.

\section{References}

Abbas UL, Glaubius R, Mubayi A, Hood G, Mellors JW. Antiretroviral therapy and pre-exposure prophylaxis: combined impact on HIV transmission and drug resistance in South Africa. The Journal of infectious diseases. 2013; 208(2):224-234.

Abela IA, Berlinger L, Schanz M, Reynell L, Günthard HF, Rusert P, Trkola A. Cell-cell transmission enables HIV-1 to evade inhibition by potent CD4bs directed antibodies. PLoS pathogens. 2012; 8(4):e1002634.

Agosto LM, Herring MB, Mothes W, Henderson AJ. HIV-1-Infected CD4+ T Cells Facilitate Latent Infection of Resting CD4+ T Cells through Cell-Cell Contact. Cell reports. 2018; 24(8):2088-2100.

Agosto LM, Uchil PD, Mothes W. HIV cell-to-cell transmission: effects on pathogenesis and antiretroviral therapy. Trends in microbiology. 2015; 23(5):289-295.

Anderson J, Cooper D. cost-effectiveness of pre-exposure prophylaxis for Hiv in an Msm population: Bpd1/6. Hiv Medicine. 2009; 10:39.

Anderson PL, Glidden DV, Liu A, Buchbinder S, Lama JR, Guanira JV, McMahan V, Bushman LR, Casapía M, Montoya-Herrera O, Veloso VG, Mayer KH, Chariyalertsak S, Schechter M, Bekker LG, Kallás EG, Grant RM. Emtricitabine-tenofovir concentrations and pre-exposure prophylaxis efficacy in men who have sex with men. Science translational medicine. 2012; 4(151):151 ra125-151ra125.

Anderson PL, Kiser JJ, Gardner EM, Rower JE, Meditz A, Grant RM. Pharmacological considerations for tenofovir and emtricitabine to prevent HIV infection. Journal of Antimicrobial Chemotherapy. 2010; 66(2):240-250.

Andrews CD, Heneine W. Cabotegravir long-acting for HIV-1 prevention. Current Opinion in HIV and AIDS. 2015; 10(4):258-263.

Arts EJ, Hazuda DJ. HIV-1 antiretroviral drug therapy. Cold Spring Harbor perspectives in medicine. 2012; 2(4):a007161.

Athreya KB, Ney PE, Ney P. Branching processes. Courier Corporation; 2004.

Baeten JM, Donnell D, Ndase P, Mugo NR, Campbell JD, Wangisi J, Tappero JW, Bukusi EA, Cohen CR, Katabira E, Ronald A, Tumwesigye E, Were E, Fife KH, Kiarie J, Farquhar C, John-Stewart G, Kakia A, Odoyo J, Mucunguzi A, Nakku-Joloba E, Twesigye R, Ngure K, Apaka C, Tamooh H, Gabona F, Mujugira A, Panteleeff D, Thomas KK, Kidoguchi L, Krows M, Revall J, Morrison S, Haugen H, Emmanuel-Ogier M, Ondrejcek L, Coombs RW, Frenkel L, Hendrix C, Bumpus NN, Bangsberg D, Haberer JE, Stevens WS, Lingappa JR, Celum C. Antiretroviral prophylaxis for HIV prevention in heterosexual men and women. New England Journal of Medicine. 2012; 367(5):399-410.

Baeten JM, Haberer JE, Liu AY, Sista N. Pre-exposure prophylaxis for HIV prevention: where have we been and where are we going? Journal of acquired immune deficiency syndromes (1999). 2013; 63(0 2):S122.

Baeten JM, Palanee-Phillips T, Brown ER, Schwartz K, Soto-Torres LE, Govender V, Mgodi NM, Matovu Kiweewa F, Nair G, Mhlanga F, Siva S, Bekker LG, Jeenarain N, Gaffoor Z, Martinson F, Makanani B, Pather A, Naidoo L, Husnik M, Richardson BA, Parikh UM, Mellors JW, Marzinke MA, Hendrix CW, van der Straten A, Ramjee G, Chirenje ZM, Nakabiito C, Taha TE, Jones J, Mayo A, Scheckter R, Berthiaume J, Livant E, Jacobson C, Ndase P, White R, Patterson K, Germuga D, Galaska B, Bunge K, Singh D, Szydlo DW, Montgomery ET, Mensch BS, Torjesen K, Grossman Cl, Chakhtoura N, Nel A, Rosenberg Z, et al. Use of a vaginal ring containing dapivirine for HIV-1 prevention in women. New England Journal of Medicine. 2016; 375(22):2121-2132. 
Baxter AE, Russell RA, Duncan CJ, Moore MD, Willberg CB, Pablos JL, Finzi A, Kaufmann DE, Ochsenbauer C, Kappes JC, Groot F, Sattentau QJ. Macrophage infection via selective capture of HIV-1-infected CD4+ T cells. Cell host \& microbe. 2014; 16(6):711-721.

Boullé M, Müller TG, Dähling S, Ganga Y, Jackson L, Mahamed D, Oom L, Lustig G, Neher RA, Sigal A. HIV cell-tocell spread results in earlier onset of viral gene expression by multiple infections per cell. PLoS pathogens. 2016; 12(11):e1005964.

Chen HY, Di Mascio M, Perelson AS, Ho DD, Zhang L. Determination of virus burst size in vivo using a single-cycle SIV in rhesus macaques. Proceedings of the National Academy of Sciences. 2007; 104(48):19079-19084.

Choopanya K, Martin M, Suntharasamai P, Sangkum U, Mock PA, Leethochawalit M, Chiamwongpaet S, Kitisin P, Natrujirote P, Kittimunkong S, Chuachoowong R, Gvetadze RJ, McNicholl JM, Paxton LA, Curlin ME, Hendrix CW, Vanichseni S. Antiretroviral prophylaxis for HIV infection in injecting drug users in Bangkok, Thailand (the Bangkok Tenofovir Study): a randomised, double-blind, placebo-controlled phase 3 trial. The Lancet. 2013; 381(9883):2083-2090.

Chun TW, Carruth L, Finzi D, Shen X, DiGiuseppe JA, Taylor H, Hermankova M, Chadwick K, Margolick J, Quinn TC, Kuo YH, Brookmeyer R, Zeiger MA, Barditch-Crovo P, Siliciano RF. Quantification of latent tissue reservoirs and total body viral load in HIV-1 infection. Nature. 1997; 387(6629):183-188.

Chun TW, Stuyver L, Mizell SB, Ehler LA, Mican JAM, Baseler M, Lloyd AL, Nowak MA, Fauci AS. Presence of an inducible HIV-1 latent reservoir during highly active antiretroviral therapy. Proceedings of the National Academy of Sciences. 1997; 94(24):13193-13197.

Churchill MJ, Deeks SG, Margolis DM, Siliciano RF, Swanstrom R. HIV reservoirs: what, where and how to target them. Nature Reviews Microbiology. 2016; 14(1):55.

Deeks SG, Smith M, Holodniy M, Kahn JO. HIV-1 protease inhibitors: a review for clinicians. Jama. 1997; 277(2):145-153.

Del Portillo A, Tripodi J, Najfeld V, Wodarz D, Levy DN, Chen BK. Multiploid inheritance of HIV-1 during cell-to-cell infection. Journal of virology. 2011; p. JVI-00231.

Delbrück M. The burst size distribution in the growth of bacterial viruses (bacteriophages). Journal of bacteriology. 1945; 50(2):131.

Desai K, Sansom SL, Ackers ML, Stewart SR, Hall HI, Hu DJ, Sanders R, Scotton CR, Soorapanth S, Boily MC, Garnett GP, McElroy P. Modeling the impact of HIV chemoprophylaxis strategies among men who have sex with men in the United States: HIV infections prevented and cost-effectiveness. Aids. 2008; 22(14):1829-1839.

Dimitrov D, Boily MC, Brown ER, Hallett TB. Analytic review of modeling studies of ARV based PrEP interventions reveals strong influence of drug-resistance assumptions on the population-level effectiveness. PLoS One. 2013; 8(11):e80927.

Dolling D, Phillips A, Delpech V, Pillay D, Cane P, Crook A, Shepherd J, Fearnhill E, Hill T, Dunn D. Evaluating the extent of potential resistance to pre-exposure prophylaxis within the UK HIV-1-infectious population of men who have sex with men. HIV medicine. 2012; 13(5):309-314.

Duncan CJ, Williams JP, Schiffner T, Gärtner K, Ochsenbauer C, Kappes J, Russell RA, Frater J, Sattentau QJ. Highmultiplicity HIV-1 infection and neutralizing antibody evasion mediated by the macrophage-T cell virological synapse. Journal of virology. 2014; 88(4):2025-2034.

Eckstein DA, Penn ML, Korin YD, Scripture-Adams DD, Zack JA, Kreisberg JF, Roederer M, Sherman MP, Chin PS, Goldsmith MA. HIV-1 actively replicates in naive CD4+ T cells residing within human lymphoid tissues. Immunity. 2001; 15(4):671-682.

Eriksson S, Graf EH, Dahl V, Strain MC, Yukl SA, Lysenko ES, Bosch RJ, Lai J, Chioma S, Emad F, Abdel-Mohsen M, Hoh R, Hecht F, Hunt P, Somsouk M, Wong J, Johnston R, Siliciano RF, Richman DD, O'Doherty U, Palmer S, Deeks SG, Siliciano JD. Comparative analysis of measures of viral reservoirs in HIV-1 eradication studies. PLoS pathogens. 2013; 9(2):e1003174.

Finzi D, Blankson J, Siliciano JD, Margolick JB, Chadwick K, Pierson T, Smith K, Lisziewicz J, Lori F, Flexner C, Quinn TC, Chaisson RE, Rosenberg E, Walker B, Gange S, Gallant J, Siliciano RF. Latent infection of CD4+ T cells provides a mechanism for lifelong persistence of HIV-1, even in patients on effective combination therapy. Nature medicine. 1999; 5(5):512. 
García-Lerma JG, Otten RA, Qari SH, Jackson E, Cong Me, Masciotra S, Luo W, Kim C, Adams DR, Monsour M, Lipscomb J, Johnson JA, Delinsky D, Schinazi RF, Janssen R, M Folks T, Heneine W. Prevention of rectal SHIV transmission in macaques by daily or intermittent prophylaxis with emtricitabine and tenofovir. PLoS medicine. 2008; 5(2):e28.

Gomez GB, Borquez A, Caceres CF, Segura ER, Grant RM, Garnett GP, Hallett TB. The potential impact of preexposure prophylaxis for HIV prevention among men who have sex with men and transwomen in Lima, Peru: a mathematical modelling study. PLoS medicine. 2012; 9(10):e1001323.

Gradshteyn IS, Ryzhik IM. Table of integrals, series, and products. Academic press; 2014.

Grant RM, Anderson PL, McMahan V, Liu A, Amico KR, Mehrotra M, Hosek S, Mosquera C, Casapia M, Montoya O, Buchbinder S, Veloso VG, Mayer K, Chariyalertsak S, Bekker LG, Kallas EG, Schechter M, Guanira J, Bushman L, Burns DN, Rooney JF, Glidden DV, iPrEx study team. Uptake of pre-exposure prophylaxis, sexual practices, and HIV incidence in men and transgender women who have sex with men: a cohort study. The Lancet infectious diseases. 2014; 14(9):820-829.

Grant RM, Lama JR, Anderson PL, McMahan V, Liu AY, Vargas L, Goicochea P, Casapía M, Guanira-Carranza JV, Ramirez-Cardich ME, Montoya-Herrera O, Fernández T, Veloso VG, Buchbinder SP, Chariyalertsak S, Schechter M, Bekker LG, Mayer KH, Kallás EG, Amico KR, Mulligan K, Bushman LR, Hance RJ, Ganoza C, Defechereux P, Postle B, Wang F, McConnell J, Zheng JH, Lee J, Rooney JF, Jaffe HS, Martinez Al, Burns DN, Glidden DV. Preexposure chemoprophylaxis for HIV prevention in men who have sex with men. New England Journal of Medicine. 2010; 363(27):2587-2599.

Gray RH, Wawer MJ, Brookmeyer R, Sewankambo NK, Serwadda D, Wabwire-Mangen F, Lutalo T, Li X, Quinn TC. Probability of HIV-1 transmission per coital act in monogamous, heterosexual, HIV-1-discordant couples in Rakai, Uganda. The Lancet. 2001; 357(9263):1149-1153.

Grimmett G, Stirzaker D. Probability and random processes. Oxford university press; 2001.

Hallett TB, Baeten JM, Heffron R, Barnabas R, De Bruyn G, Cremin Í, Delany S, Garnett GP, Gray G, Johnson L, McIntyre J, Rees H, Celum C, Salomon JA. Optimal uses of antiretrovirals for prevention in HIV-1 serodiscordant heterosexual couples in South Africa: a modelling study. PLoS medicine. 2011; 8(11):e1001123.

Jackson L, Hunter J, Cele S, Ferreira IM, Young AC, Karim F, Madansein R, Dullabh KJ, Chen CY, Buckels NJ, Ganga Y, Khan K, Boulle M, Lustig G, Neher RA, Sigal A. Incomplete inhibition of HIV infection results in more HIV infected lymph node cells by reducing cell death. eLife. 2018; 7:e30134.

Jin F, Jansson J, Law M, Prestage GP, Zablotska I, Imrie JC, Kippax SC, Kaldor JM, Grulich AE, Wilson DP. Per-contact probability of HIV transmission in homosexual men in Sydney in the era of HAART. AIDS (London, England). 2010; 24(6):907.

Jolly C, Kashefi K, Hollinshead M, Sattentau QJ. HIV-1 cell to cell transfer across an Env-induced, actin-dependent synapse. Journal of Experimental Medicine. 2004; 199(2):283-293.

Karim QA, Karim SSA, Frohlich JA, Grobler AC, Baxter C, Mansoor LE, Kharsany AB, Sibeko S, Mlisana KP, Omar Z, et al. Effectiveness and safety of tenofovir gel, an antiretroviral microbicide, for the prevention of HIV infection in women. science. 2010; p. 1193748.

Keele BF, Giorgi EE, Salazar-Gonzalez JF, Decker JM, Pham KT, Salazar MG, Sun C, Grayson T, Wang S, Li H, Wei X, Jiang C, Kirchherr JL, Gao F, Anderson JA, Ping LH, Swanstrom R, Tomaras GD, Blattner WA, Goepfert PA, Kilby JM, Saag MS, Delwart EL, Busch MP, Cohen MS, Montefiori DC, Haynes BF, Gaschen B, Athreya GS, Lee HY, Wood N, Seoighe C, Perelson AS, Bhattacharya T, Korber BT, Hahn BH, Shaw GM. Identification and characterization of transmitted and early founder virus envelopes in primary HIV-1 infection. Proceedings of the National Academy of Sciences. 2008; 105(21):7552-7557.

Kim JT, Chang E, Sigal A, Baltimore D. Dendritic cells efficiently transmit HIV to T Cells in a tenofovir and raltegravir insensitive manner. PloS one. 2018; 13(1):e0189945.

Koechlin FM, Fonner VA, Dalglish SL, OReilly KR, Baggaley R, Grant RM, Rodolph M, Hodges-Mameletzis I, Kennedy CE. Values and preferences on the use of oral pre-exposure prophylaxis (PrEP) for HIV prevention among multiple populations: a systematic review of the literature. AIDS and Behavior. 2017; 21(5):1325-1335.

Law KM, Komarova NL, Yewdall AW, Lee RK, Herrera OL, Wodarz D, Chen BK. In vivo HIV-1 cell-to-cell transmission promotes multicopy micro-compartmentalized infection. Cell reports. 2016; 15(12):2771-2783. 
Len AC, Starling S, Shivkumar M, Jolly C. HIV-1 activates T cell signaling independently of antigen to drive viral spread. Cell reports. 2017; 18(4):1062-1074.

Marrazzo JM, Ramjee G, Richardson BA, Gomez K, Mgodi N, Nair G, Palanee T, Nakabiito C, Van Der Straten A, Noguchi L, Hendrix CW, Dai JY, Ganesh S, Mkhize B, Taljaard M, Parikh UM, Piper J, Masse B, Grossman C, Rooney J, Schwartz JL, Watts H, Marzinke MA, Hillier SL, McGowan IM, Chirenje ZM, Team VS. Tenofovir-based preexposure prophylaxis for HIV infection among African women. New England Journal of Medicine. 2015; 372(6):509-518.

McCormack S, Dunn DT, Desai M, Dolling DI, Gafos M, Gilson R, Sullivan AK, Clarke A, Reeves I, Schembri G, Mackie N, Bowman C, Lacey CJ, Apea V, Brady M, Fox J, Taylor S, Antonucci S, Khoo SH, Rooney J, Nardone A, Fisher M, McOwan A, Phillips AN, Johnson AM, Gazzard B, Gill ON. Pre-exposure prophylaxis to prevent the acquisition of HIV-1 infection (PROUD): effectiveness results from the pilot phase of a pragmatic open-label randomised trial. The Lancet. 2016; 387(10013):53-60.

Molina JM, Capitant C, Spire B, Pialoux G, Cotte L, Charreau I, Tremblay C, Le Gall JM, Cua E, Pasquet A, et al. On-demand preexposure prophylaxis in men at high risk for HIV-1 infection. New England Journal of Medicine. 2015; 373(23):2237-2246.

Molla A, Korneyeva M, Gao Q, Vasavanonda S, Schipper PJ, Mo HM, Markowitz M, Chernyavskiy T, Niu P, Lyons N, Hsu A, Granneman GR, Ho DD, Boucher CA, Leonard JM, Norbeck DW, Kempf DJ. Ordered accumulation of mutations in HIV protease confers resistance to ritonavir. Nature medicine. 1996; 2(7):760-766.

Murnane PM, Celum C, Nelly M, Campbell JD, Donnell D, Bukusi E, Mujugira A, Tappero J, Kahle EM, Thomas KK, Baeten JM. Efficacy of pre-exposure prophylaxis for HIV-1 prevention among high risk heterosexuals: subgroup analyses from the Partners PrEP Study. AIDS (London, England). 2013; 27(13).

Nel A, van Niekerk N, Kapiga S, Bekker LG, Gama C, Gill K, Kamali A, Kotze P, Louw C, Mabude Z, Miti N, Kusemererwa S, Tempelman H, Carstens H, Devlin B, Isaacs M, Malherbe M, Mans W, Nuttall J, Russell M, Ntshele S, Smit M, Solai L, Spence P, Steytler J, Windle K, Borremans M, Resseler S, Van Roey J, Parys W, Vangeneugden T, Van Baelen B, Rosenberg Z, Team RS. Safety and efficacy of a dapivirine vaginal ring for HIV prevention in women. New England Journal of Medicine. 2016; 375(22):2133-2143.

Nichols BE, Boucher CA, van der Valk M, Rijnders BJ, van de Vijver DA. Cost-effectiveness analysis of preexposure prophylaxis for HIV-1 prevention in the Netherlands: a mathematical modelling study. The Lancet Infectious Diseases. 2016; 16(12):1423-1429.

Nowak M, May RM. Virus dynamics: mathematical principles of immunology and virology: mathematical principles of immunology and virology. Oxford University Press, UK; 2000.

Okano JT, Blower S. HIV treatment, preexposure prophylaxis, and drug resistance: reconciling conflicting predictions from mathematical models. The Journal of infectious diseases. 2013; 209(1):163-164.

Paltiel AD, Freedberg KA, Scott CA, Schackman BR, Losina E, Wang B, Seage GR, Sloan CE, Sax PE, Walensky RP. HIV preexposure prophylaxis in the United States: impact on lifetime infection risk, clinical outcomes, and cost-effectiveness. Clinical Infectious Diseases. 2009; 48(6):806-815.

Patterson KB, Prince HA, Kraft E, Jenkins AJ, Shaheen NJ, Rooney JF, Cohen MS, Kashuba AD. Penetration of tenofovir and emtricitabine in mucosal tissues: implications for prevention of HIV-1 transmission. Science translational medicine. 2011; 3(112):112re4-112re4.

Perelson AS, Neumann AU, Markowitz M, Leonard JM, Ho DD. HIV-1 dynamics in vivo: virion clearance rate, infected cell life-span, and viral generation time. Science. 1996; 271(5255):1582-1586.

Pretorius C, Stover J, Bollinger L, Bacaër N, Williams B. Evaluating the cost-effectiveness of pre-exposure prophylaxis (PrEP) and its impact on HIV-1 transmission in South Africa. PloS one. 2010; 5(11):e13646.

Punyacharoensin N, John Edmunds W, Angelis D, Delpech V, Hart G, Elford J, Brown A, Gill O, White R. Effect of pre-exposure prophylaxis and combination HIV prevention for men who have sex with men in the UK: $A$ mathematical modelling study. . $201601 ; 3$.

Rabi SA, Laird GM, Durand CM, Laskey S, Shan L, Bailey JR, Chioma S, Moore RD, Siliciano RF. Multi-step inhibition explains HIV-1 protease inhibitor pharmacodynamics and resistance. The Journal of clinical investigation. 2013; 123(9):3848-3860.

Ribeiro RM, Qin L, Chavez LL, Li D, Self SG, Perelson AS. Estimation of the initial viral growth rate and basic reproductive number during acute HIV-1 infection. Journal of virology. 2010; 84(12):6096-6102. 
Rudnicka D, Feldmann J, Porrot F, Wietgrefe S, Guadagnini S, Prévost MC, Estaquier J, Haase AT, Sol-Foulon N, Schwartz O. Simultaneous cell-to-cell transmission of human immunodeficiency virus to multiple targets through polysynapses. Journal of virology. 2009; 83(12):6234-6246.

Saenz RA, Bonhoeffer S. Nested model reveals potential amplification of an HIV epidemic due to drug resistance. Epidemics. 2013; 5(1):34-43.

Sherer NM, Lehmann MJ, Jimenez-Soto LF, Horensavitz C, Pypaert M, Mothes W. Retroviruses can establish filopodial bridges for efficient cell-to-cell transmission. Nature cell biology. 2007; 9(3):310.

Sigal A, Baltimore D. As good as it gets? The problem of HIV persistence despite antiretroviral drugs. Cell host \& microbe. 2012; 12(2):132-138.

Sigal A, Kim JT, Balazs AB, Dekel E, Mayo A, Milo R, Baltimore D. Cell-to-cell spread of HIV permits ongoing replication despite antiretroviral therapy. Nature. 2011; 477(7362):95.

Siliciano JD, Kajdas J, Finzi D, Quinn TC, Chadwick K, Margolick JB, Kovacs C, Gange SJ, Siliciano RF. Long-term follow-up studies confirm the stability of the latent reservoir for HIV-1 in resting CD4+ T cells. Nature medicine. 2003; 9(6):727.

Sowinski S, Jolly C, Berninghausen O, Purbhoo MA, Chauveau A, Köhler K, Oddos S, Eissmann P, Brodsky FM, Hopkins $C$, et al. Membrane nanotubes physically connect T cells over long distances presenting a novel route for HIV-1 transmission. Nature cell biology. 2008; 10(2):211.

Spinner CD, Boesecke C, Zink A, Jessen H, Stellbrink HJ, Rockstroh JK, Esser S. HIV pre-exposure prophylaxis (PrEP): a review of current knowledge of oral systemic HIV PrEP in humans. Infection. 2016; 44(2):151-158.

Supervie V, Barrett M, Kahn JS, Musuka G, Moeti TL, Busang L, Blower S. Modeling dynamic interactions between pre-exposure prophylaxis interventions \& treatment programs: predicting HIV transmission \& resistance. Scientific reports. 2011; 1:185.

Supervie V, García-Lerma JG, Heneine W, Blower S. HIV, transmitted drug resistance, and the paradox of preexposure prophylaxis. Proceedings of the National Academy of Sciences. 2010; 107(27):12381-12386.

Thigpen MC, Kebaabetswe PM, Paxton LA, Smith DK, Rose CE, Segolodi TM, Henderson FL, Pathak SR, Soud FA, Chillag R Kata L Mutanhaurwa, Chirwa LI, Kasonde M, Abebe D, Buliva E, Gvetadze RJ, Johnson S, Sukalac T, Thomas VT, Hart C, Johnson JA, Malotte CK, Hendrix CW, Brooks JT. Antiretroviral preexposure prophylaxis for heterosexual HIV transmission in Botswana. New England Journal of Medicine. 2012; 367(5):423-434.

Van Damme L, Corneli A, Ahmed K, Agot K, Lombaard J, Kapiga S, Malahleha M, Owino F, Manongi R, Onyango J, et al. Preexposure prophylaxis for HIV infection among African women. New England Journal of Medicine. 2012; 367(5):411-422.

Van De Vijver DA, Nichols BE, Abbas UL, Boucher CA, Cambiano V, Eaton JW, Glaubius R, Lythgoe K, Mellors J, Phillips A, Sigaloff KC, Hallett TB. Preexposure prophylaxis will have a limited impact on HIV-1 drug resistance in sub-Saharan Africa: a comparison of mathematical models. Aids. 2013; 27(18):2943-2951.

Wagner JG. Fundamentals of clinical pharmacokinetics. Drug Intelligence Publications; 1975.

Wei X, Decker JM, Liu H, Zhang Z, Arani RB, Kilby JM, Saag MS, Wu X, Shaw GM, Kappes JC. Emergence of resistant human immunodeficiency virus type 1 in patients receiving fusion inhibitor (T-20) monotherapy. Antimicrobial agents and chemotherapy. 2002; 46(6):1896-1905.

WHO. Guideline on when to start antiretroviral therapy and on pre-exposure prophylaxis for HIV, web supplement: annex 2: evidence to decision-making tables and supporting evidence. World Health Organization; 2015.

Wu Y, Beddall MH, Marsh JW. Rev-dependent indicator T cell line. Current HIV research. 2007; 5(4):394-402.

Zhong P, Agosto LM, Ilinskaya A, Dorjbal B, Truong R, Derse D, Uchil PD, Heidecker G, Mothes W. Cell-to-cell transmission can overcome multiple donor and target cell barriers imposed on cell-free HIV. PloS one. 2013; 8(1):e53138. 

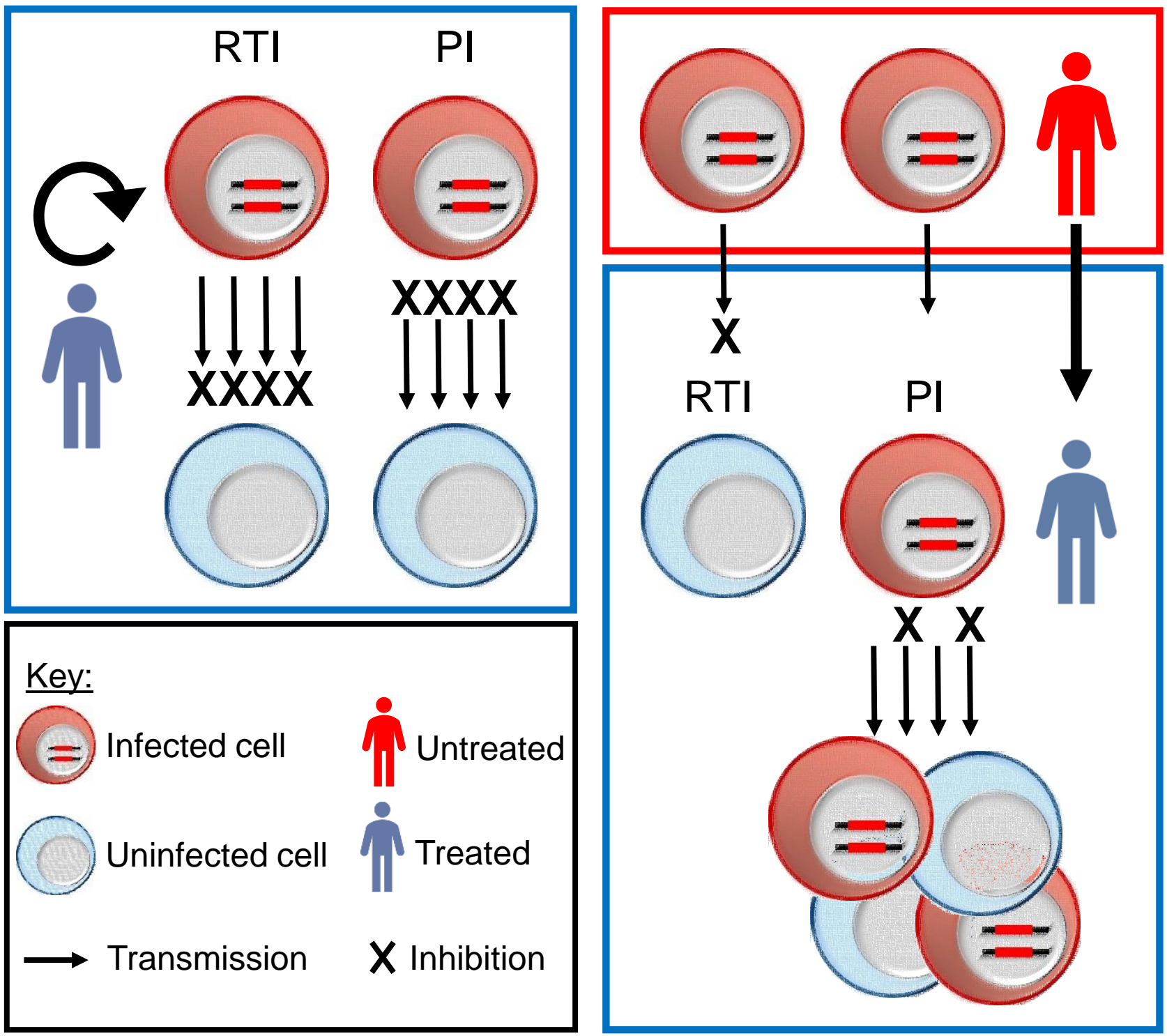
A

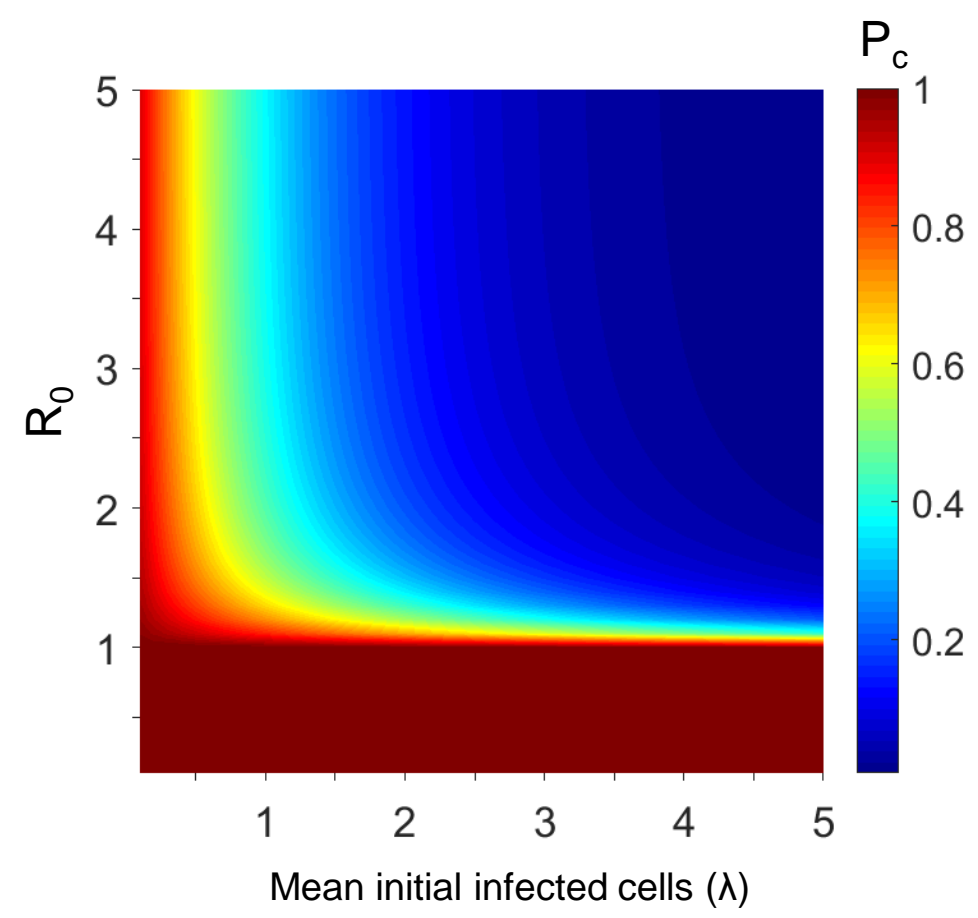

B
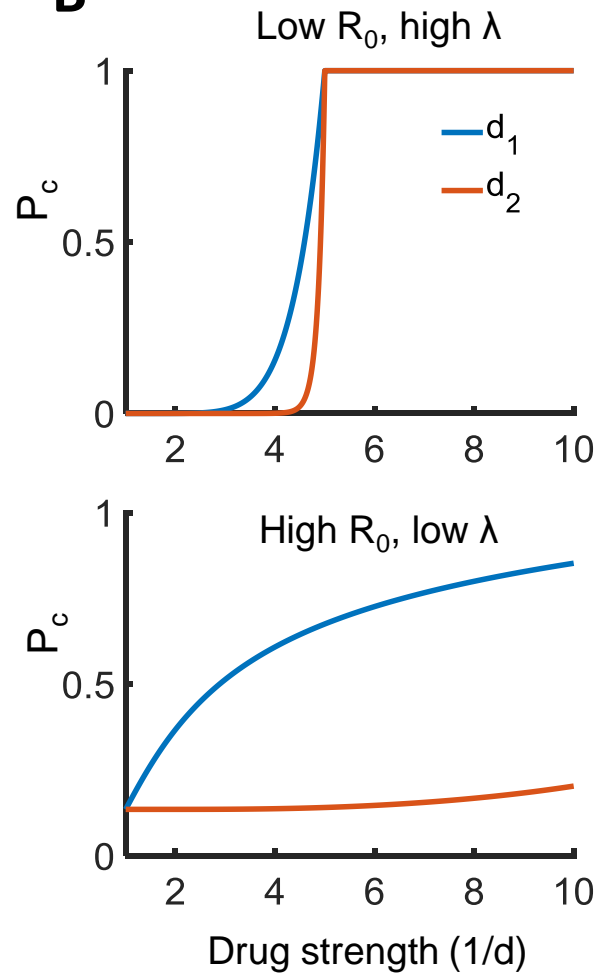


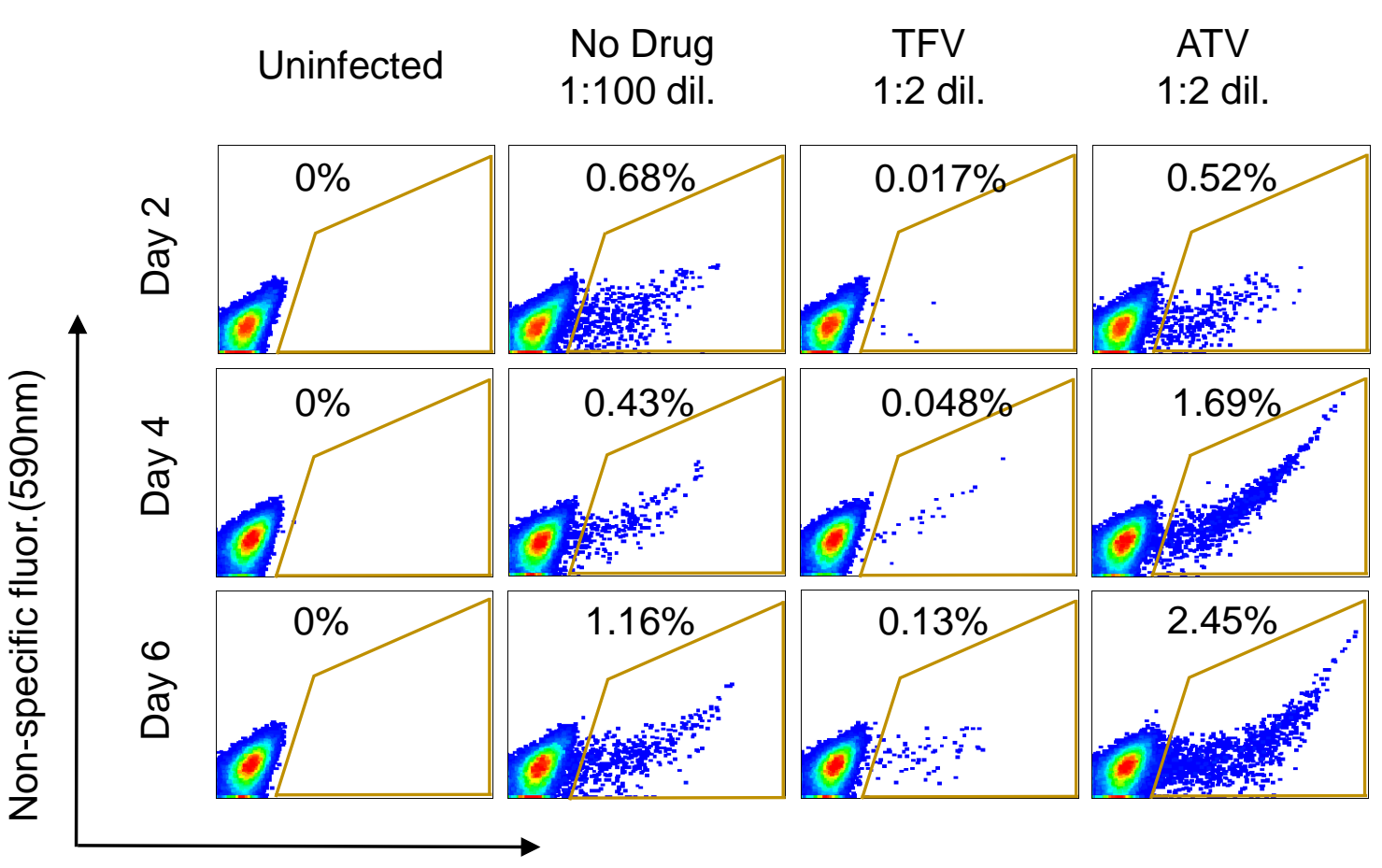

Infection (GFP, 535nm)

B
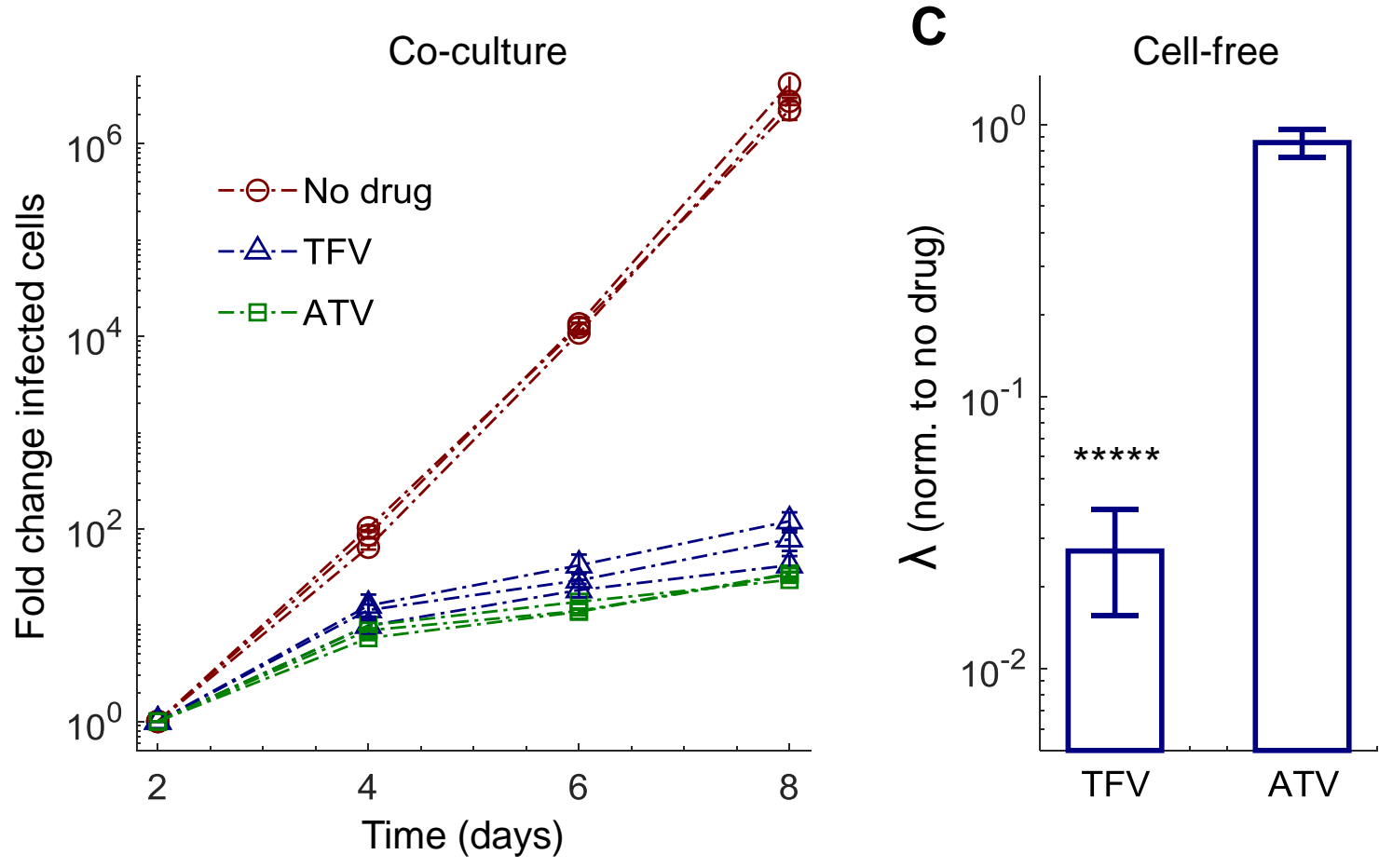


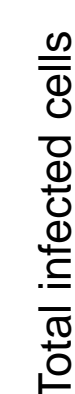

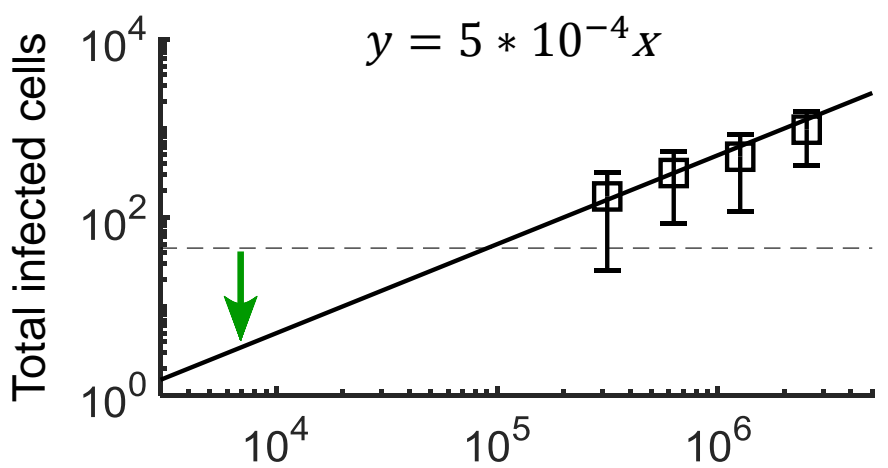

Input cell-free HIV copies

C

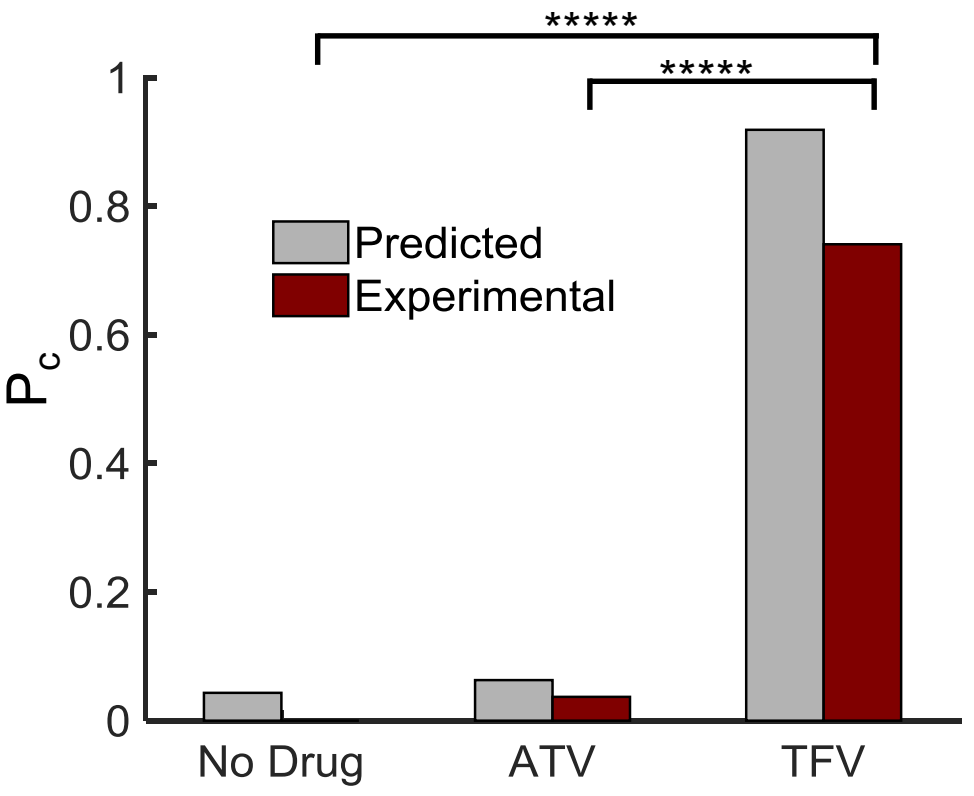

Uninfected
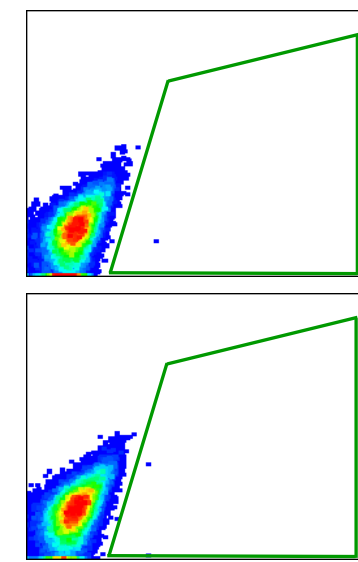

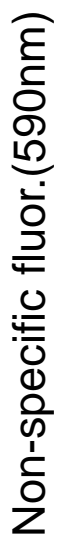
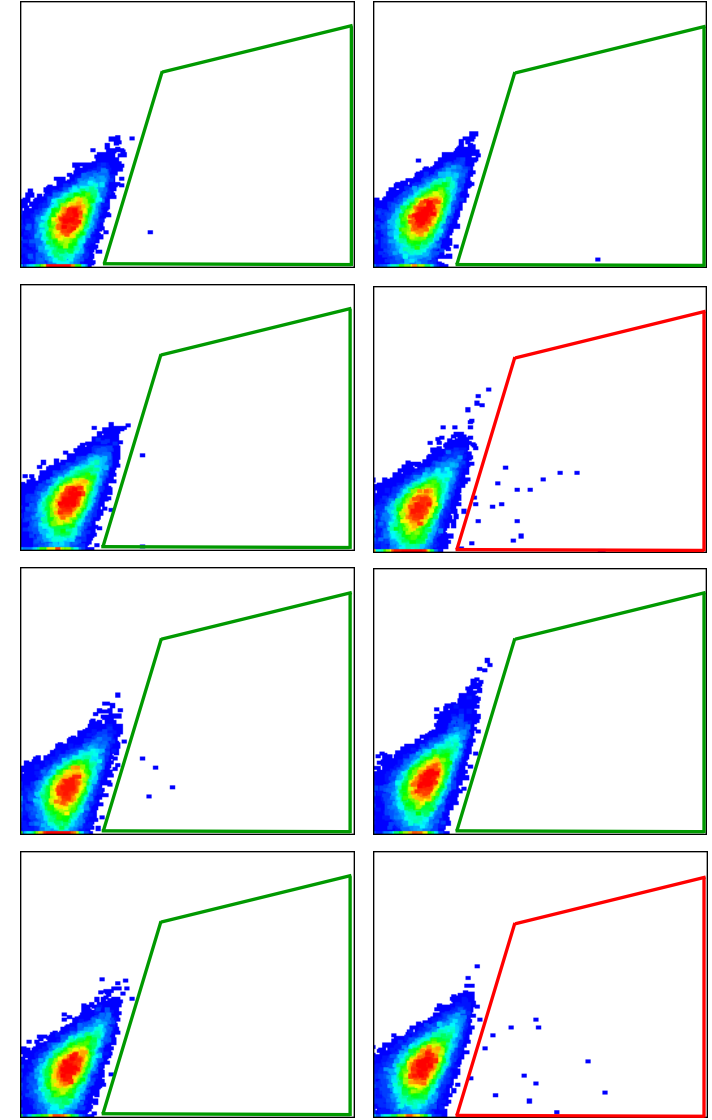

\section{政}
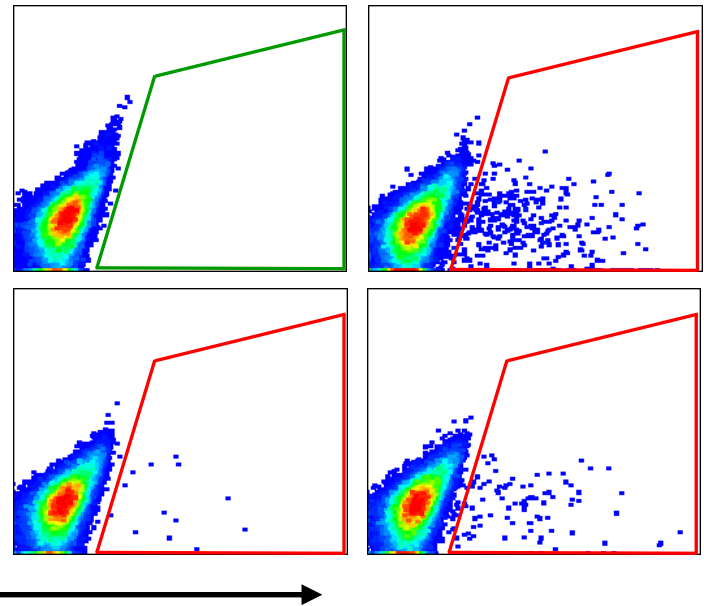

Infection (GFP, 535nm)
ATV
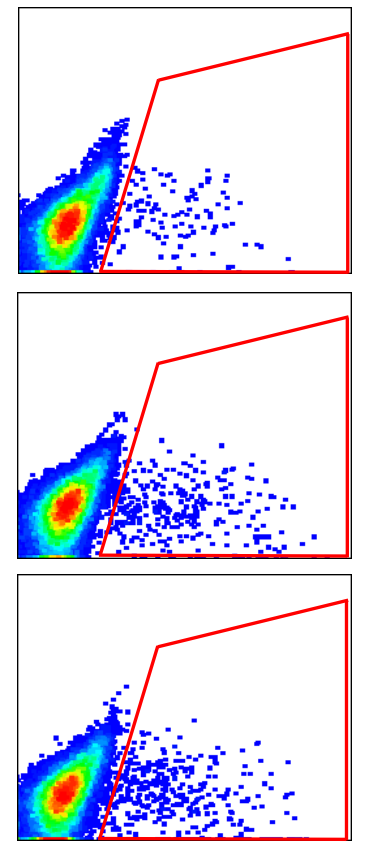